\title{
Study of Radon concentrations in a single-family home and their relationship with the ventilation system
}

\author{
Pablo Villalba Espinosa (Main author) \\ Higher Technical School of Building Engineering, University of Granada \\ Campus Fuentenueva, 18071, Granada (Spain) \\ bikergrmtb@correo.ugr.es \\ http://orcid.org/0000-0003-3003-4909
}

David Hidalgo García (Corresponding author)

Higher Technical School of Building Engineering, University of Granada

Campus Fuentenueva, 18071, Granada (Spain)

dhidalgo@ugr.es

http://orcid.org/0000-0002-4039-8709

\section{Julián Arco Díaz}

Higher Technical School of Building Engineering, University of Granada. Campus Fuentenueva, 18071, Granada (Spain)

juliannn@ugr.es

http://orcid.org/0000-0002-6894-6084

\section{Juan Villallba Moreno}

Faculty of Dentistry, University of Granada

Campus Cartuja. 18071, Granada (Spain)

jvillal@ugr.es

http://orcid.org/0000-0003-0894-9280

Manuscript Code: 14070

Date of Acceptance/Reception: 30.11.2020/15.09.2019

DOI: 10.7764/RDLC.19.3.443

\begin{abstract}
In the past decade a number of studies have looked into the environmental conditions of buildings and the quality of air indoors, in light of scientific reports that link them to serious illnesses. Outstanding among these studies are the ones focusing on the concentration of Radon gas, qualified as a grade one carcinogen. Our article analyzes the concentrations of this gas detected in a single-family home and how the levels may be affected by the ventilation system used. Air samples were taken under different conditions - the first sample without ventilation of the space and the second with ventilation - in three units of the house: garage, living room and bedroom. The maximum concentrations obtained when the ventilation system was not in operation show values between 94.45 and $391.12 \mathrm{~Bq} / \mathrm{m}^{3}$, obtaining an average of $278.86 \mathrm{~Bq} / \mathrm{m}^{3}$, being above the recommended ideal threshold established by the World Health Organization. In contrast, the maximum concentrations were between 71.56 and $29.98 \mathrm{~Bq} / \mathrm{m}^{3} \mathrm{when}$ the ventilation system was used. Our results confirm that ventilation is decisive for reducing the concentration of gas in interiors, giving an average efficiency of $62 \%$.
\end{abstract}

Keywords: Concentration, building, mitigation, Radon, ventilation.

Radon gas was discovered in 1900 by the German physicist Fiedrich Ernst Dorn. This noble gas is emanated naturally from the earth's crust, and can have different origins: Uranium-235, Thorium-232 or Uranium-238 (NSCS, 2010a). The first of them decays into the Rn-219 isotope called Actinon. It is the least abundant in the earth's crust, and because it has a very short radioactive half-life (3.96 seconds), it is considered to be of almost zero risk. The second disintegrates into the $\mathrm{Rn}-220$ isotope called Toron, and although it is the most abundant one in the subsoil, it presents a medium risk because it also has a relatively short radioactive life (55.8 seconds). The last of the three, Uranium-238, has as its decendant Radon-222. It entails the highest risk, having a long radioactive half-life of 3.2823 days (AENOR, 2016; Frutos et al., 2014).

Uranium-238 is a very active chemical element that is present in various proportions in almost all the rocks on the planet, in water from the subsoil, and even in some construction materials (Liu et al., 2017). Its descendant, Rn-222, is 
a radioactive gas that is harmful to health; it can circulate to the surface atmosphere due to many factors - but mainly due to the porosity of materials where it is diluted - and may penetrate buildings. In open spaces it does not pose a great risk, and when mixed with other gases, its concentration decreases to levels between 5 and 15 Bq/m3 (WHO, 2015). Yet in closed spaces, due to the lack of ventilation, its concentration may increase to very dangerous values for living beings, as it is able to alter the DNA of lung tissue, giving rise to mutations and cancer (IARC, 1988; SAAC, n.d.; WHO, 2014).

In 1986, the World Health Organization (WHO) classified Radon as a grade one carcinogen, and the second cause of lung cancer after tobacco smoke (WHO, 2009). The Spanish Association Against Cancer (SAAC) estimates that some 2500 people die yearly in Spain as a result of this gas (SAAC, n.d.). The United States Environmental Protection Agency (EPA) attributes the death of 21,000 Americans every year to Radon (IED, n.d.). According to recent studies involving smokers (García-Talavera et al., 2017), the percentages of mortality due to this gas at exposures of 0,100 and $400 \mathrm{~Bq} / \mathrm{m}^{3}$ are $10 \%, 12 \%$ and $16 \%$, respectively, while for non-smokers the values are $0.4 \%, 0.5 \%$ and $0.7 \%$, meaning that exposure to Radon strongly increases the possibility of developing lung cancer (Barros et al., 2002; Catelinois et al., 2006).

As can be seen in figure 1, Radon can enter buildings through walls, floors, installations, expansion joints and cracks that are in contact with the ground (NSCS, 2010b). Once inside, its presence goes undetected, owing to its inert, colorless, tasteless and odorless character (Lamonaca et al., 2014).

Figure 1. Possible pathway for Radon to enter the building. 1- Through the walls; 2- Through the hearth; 3- Through the enclosures; 4- Through the facilities; 5- Through the floors. Source: Nuclear Safety Council. Technical Report Collection 24, 2010).

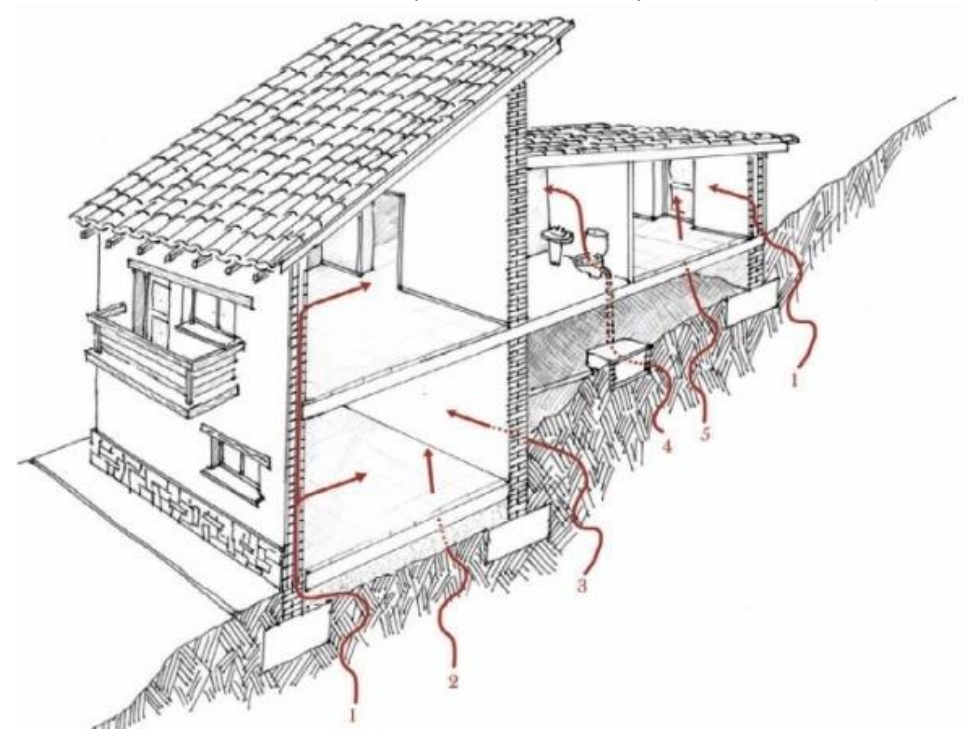

Given that nowadays people remain inside buildings some $75 \%-90 \%$ of the time (Piedecausa, 2013), and that Radon gas is found throughout the crust of the earth, international interest in this topic is growing. The foremost objectives are to obtain measurements and create systems that may be implemented to control the adverse effects of Radon on people's health.

State of Art

The initial observations of excess mortality from lung cancer as a result of Radon can be traced to 1879, in the context of underground miners. During World War II, epidemiological studies were carried out in order to assess the risks of exposure to Radon in trenches and other settings. Much of our knowledge of its carcinogenic effects comes from these investigations (García-Talavera et al., 2017). Further studies of its effects on humans have been carried out in Sweden (Axelson et al., 1979), France (Catelinois et al., 2006) and England (Miles et al., 2007).

In Spain, the study of Radon gas concentrations began in underground scenarios: Uranium mines (Quindós et al., 2004), the touristic caves of Altamira (Lario et al., 2005) and Nerja (Dueñas et al., 2011), or volcanic caves in Tenerife (Pinza et al., 1999). In 2009-2010 a group of researchers from the University of Extremadura carried out a study of 130 places including museums, wineries and caves, spas, tunnels and galleries, hotels and supply facilities. The results of this investigation showed that $69 \%$ of the places studied had Radon concentrations below $200 \mathrm{~Bq} / \mathrm{m}^{3}, 18 \%$ concentrations between 200 and $400 \mathrm{~Bq} / \mathrm{m}^{3}$, and 13\% concentrations that exceeded $400 \mathrm{~Bq} / \mathrm{m}^{3}$ (Martín et al., 2012). 
One of the first studies of Radon concentrations in homes involved 228 random measurements from western Spain, and indicated that $39 \%$ of the dwellings presented values above $150 \mathrm{~Bq} / \mathrm{m}^{3}$ on average (Quindós et al., 1995). Studies carried out in Madrid (Sainz et al., 2009), Galicia (Barros et al., 2007) and Alicante (Piedecausa \& Frutos, 2018; Piedecausa, 2013) all obtained values above the guideline values established by the European Union (CEU, 2014). In the case of Galicia, measurements taken in 983 homes showed that $21.3 \%$ had values above $148 \mathrm{~Bq} / \mathrm{m}^{3}$ and $12 \%$ exceeded 200 $\mathrm{Bq} / \mathrm{m}^{3}$ (Barros et al., 2007).

Workplaces have also been the object of study. Research undertaken between 2016 and 2017 involving 248 jobs in Spain determined that the mean concentration of Radon was $251 \mathrm{~Bq} / \mathrm{m}^{3}$. Altogether, $27 \%$ of the analyzed jobs entailed exposure at concentrations higher than $300 \mathrm{~Bq} / \mathrm{m}^{3}$ (Ruano et al., 2018).

\section{Reference rules}

In Spain, the Health Protection Regulation against Ionizing Radiation (RPSRI), published in 2001, recommended conducting studies in workplaces where high concentrations might exist (MP, 2001). Subsequently, the Royal Decree $1439 / 2010$ (MP, 2010) modified the standards, making it obligatory to carry out such analyses. In 2012, the Nuclear Safety Council of Spain published Instruction I-33 (NSCS, 2011) aimed at establishing radiological criteria for radioactivity. It marks a maximum average annual Radon concentration in workplaces below $600 \mathrm{~Bq} / \mathrm{m}^{3}$. This threshold is reduced to $300 \mathrm{~Bq} / \mathrm{m}^{3}$ in the case of prolonged stays.

Directive 90/143/EURATOM was replaced by 2013/59 EURATOM, which sets forth in articles 54 and 74 an average annual concentration limit of $300 \mathrm{~Bq} / \mathrm{m}^{3}$ as the reference for both indoor work environments and homes (CEU, 2014).

In December 2019, the Spanish Royal Decree 732/2019 was approved, modifying the Technical Building Code (TBC) and bringing into force the Basic Health Document DB-HS-6, which specifically addressed protection against Radon exposure. Its article 13.6 states: "Buildings will have adequate means to limit the foreseeable risk of inappropriate exposure to Radon from the ground in closed areas" (MD, 2018: 4). In turn, its article 2 establishes a reference value of $300 \mathrm{~Bq} / \mathrm{m3}$ as the annual average limit for inhabitable indoor places. A minimum area of affected homes required to take action is not established. The opposite is true of the United Kingdom, where action is required when the affected area amounts to at least $1 \%$ of dwellings above the maximum concentration level allowed (Rees et al., 2010). So as not to exceed this value, it evokes three systems: protection barrier, ventilated space, and ground pressurization. Studies intended to establish approximate gas concentrations and the reduction effectiveness of such measures arrived at respective values around 65\%, 50\%-90\% and 99\%, respectively (Frutos el al., 2018; Frutos et al., 2014; Frutos et al., 2011; NSCS, 2010b) Ground pressurization techniques present a percentage of efficiency much higher than the other two, in some cases doubling the effectiveness of traditional ventilation systems. However, previous studies involving the latter systems (Frutos et al., 2018; Frutos et al., 2011; Muñoz et al., 2017; Otero et al., 2017) below $400 \mathrm{~Bq} / \mathrm{m}^{3}$, since mixing polluted air with the outside air reduces accumulation through dilution, giving these systems an efficiency level for reducing Radon concentration of $50 \%$, as opposed to approximately $90 \%$ for forced ventilation.

Figura 2. Radon protection effectiveness of the BRE. Source: Environmental Protection Agency, p. 5.

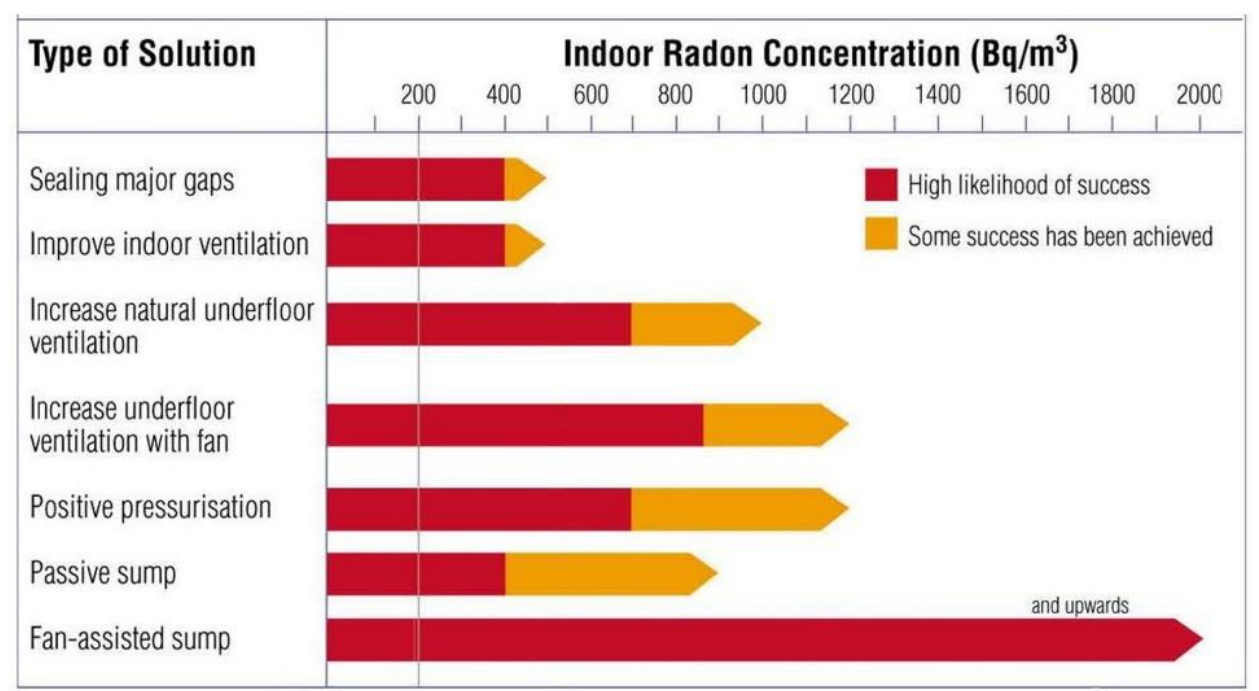


The efficacy values indicated are very similar to those that appear in Figure 2, indicating the effectiveness of protection measures documented in other countries by the UK'S Building Research Establishment Institute (NSCS, 2010b).

Data on the efficacy of ventilation systems are supported by Spain's Basic Document DB-HS-6, which explicitly states that "ventilation by itself would not be sufficient to reduce high concentrations of Radon, meaning it is necessary for more effective solutions to be implemented" (MD, 2018: 140). The WHO, in descriptive note number 291 of September 2009 , recommends a reference limit of $100 \mathrm{~Bq} / \mathrm{m}^{3}$, which in no case should exceed $300 \mathrm{~Bq} / \mathrm{m}^{3}$. In the United States, the maximum value established by the Environmental Protection Agency (EPA) is $148 \mathrm{~Bq} / \mathrm{m}^{3}$.

\section{Objective of work}

Following the indications of Spain's Royal Decrees 1439/2010 and 732/2019, the presence of this gas was studied in an isolated single-family house for residential use in the town of Dúdar, southern Spain, with the understanding that prolonged high concentrations of Radon would pose a danger to the health of its occupants.

Average concentrations of Radon were measured in various interior spaces of the building, with ventilation and without ventilation, to determine the possible level of danger and the relationship between different areas and the efficiency of the ventilation system used.

\section{Characteristics of the dwelling under study}

The dwelling under study (built in 1995) consists of a basement, below ground level, and two stories, low and high. The total dwelling area was $330 \mathrm{~m}^{2}$. The superficial foundation is secured by footings, with a reinforced concrete wall in the basement; the rest of the vertical structure is supported by reinforced concrete pillars, with unidirectional slabs of 25 $\mathrm{cm}+5 \mathrm{~cm}$ thick semi-resistant joists and ceramic vaults. The envelope is a double hollow brick double sheet enclosure with an air chamber and expanded polyurethane thermal insulation, topped by a sloping, ventilated roof of Arabic tiles and metalwork. The house does not have a forced ventilation system, only natural ventilation through its windows, which are described below and depicted in Fig. 5.

According to data from the Geological and Mining Institute of Spain (IGME), the building is located above dolomite and limestone terrain. From the hydrogeological point of view, these materials have an intermediate degree of permeability, reducing the accumulation of water in the fracture zones (IGME, 2019). The topographic conditions are hillside to medium slope. According to the categorical map of potential exposure to Radon in Spain prepared by the Nuclear Safety Council, the area pertains to category 0-low (NSCS, 2013). According to DB-HS-6 appendix B, "Classification of municipalities based on Radon potential", the house is located within zone 1.

Methodology

The methodology used to develop this research is outlined in Figure 3.

Described below are the equipment used, the variables taken into account, the places selected, and the procedure followed to take measurements.

\section{Equipment used}

To obtain the scientific data, the SARAD Radon-Scout tool was used, a device developed and manufactured in Dresden, Germany (see Fig. 4) that performs a continuous measurement of configurable intervals (minutes) during an exposure period (days) at the user's discretion. For data extraction, the Radón Vision program is used, software developed by SARAD that allows communication between the PC and the device, loading the data graphically and subtracting them in a file with a txt extension (SARAD, 2009). 

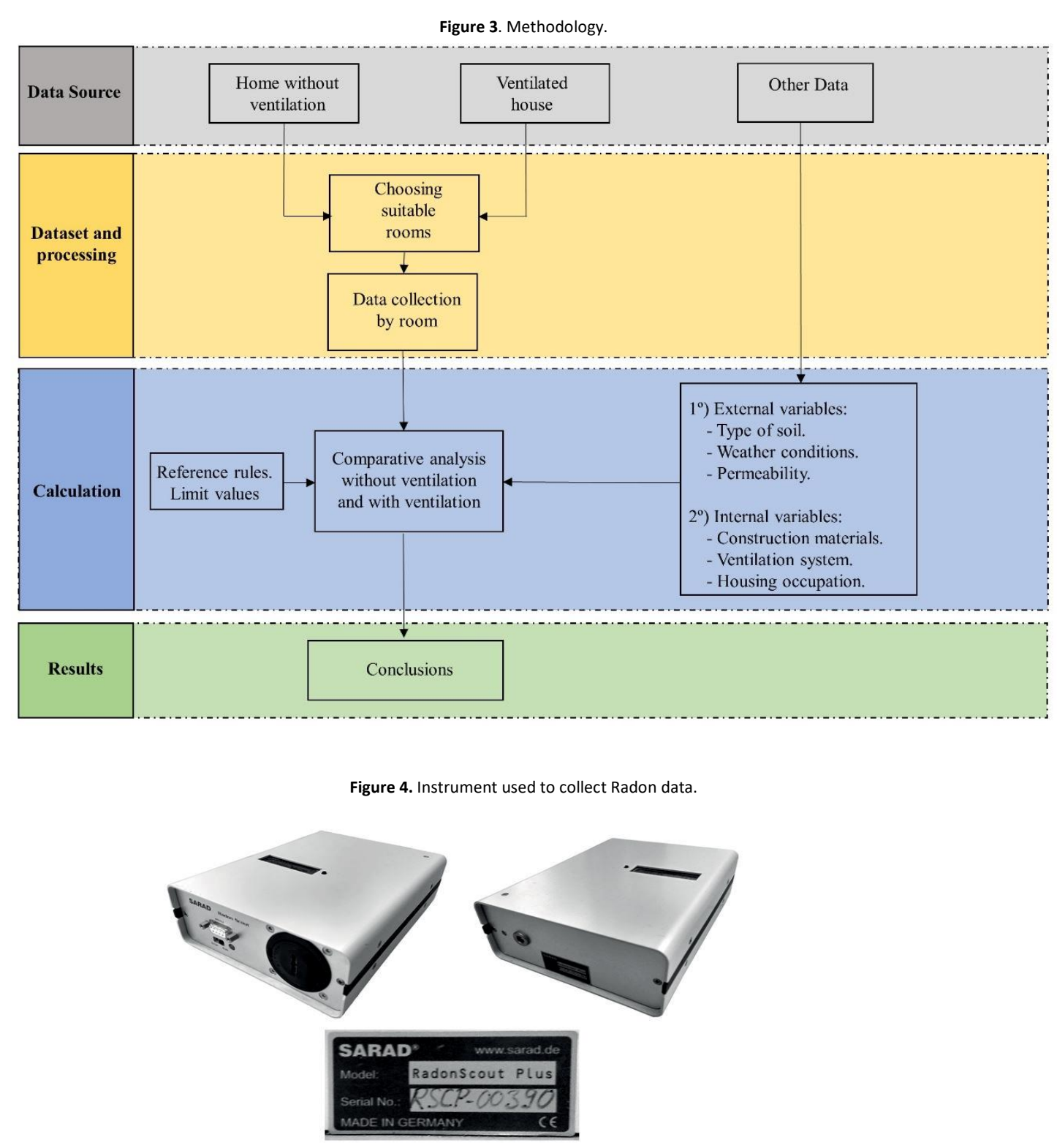

The instrument, in addition to the concentration of Radon (Rn-222) activity in ambient air, offers readings of temperature, relative humidity and barometric pressure. All data is stored in an internal memory with a capacity of up to 2047 records, the measurement periods set from 1 to 255 minutes. This equipment belongs to the Department of Radiology and Physical Medicine of the University of Granada.

\section{Variables taken into account}

Variables outside the building were taken into account (type of soil, weather conditions and permeability), along with interior variables (construction materials, ventilation system and occupation of the building). In the first place, the most suitable places for situating the measuring equipment were chosen in view of the following considerations:

19) Radon gas concentration varies from one building levels to the next, being higher in the basement and lower as one rises from the ground floor to the upper floors (Barros et al., 2007; Frutos et al., 2011).

2) Even when in the same exposition area, the concentration can vary depending on the construction type, use, or building components (Barros et al., 2007; Ruano et al., 2018).

3) Ventilation is the fundamental factor for dissipation (Frutos et al., 2011).

Regarding the ventilation of the house, we should underline that no forced ventilation system was involved. The bathrooms have exterior windows, so they do not have extractors. All the ventilation of the house takes place through the windows, which have sliding leaves, allowing an opening of $50 \%$ of the window space. Because the house is isolated 
and located in a rural area, and measurements were carried out in spring, with mild temperatures, the thermal and acoustic conditions of the house were not substantially affected. Ventilated measurements entailed opening a window throughout the interval, except for the measurement in the bedroom, where the window was closed at night.

The housing units selected for the location of the measuring instrument can be viewed in Figure 5 . In the basement, a $60 \mathrm{~m}^{2}$ room was designated as the garage of the house. It has a window to the outside measuring $1.20 \times 1.20$ meters, and an access door of $2.50 \times 2.10$ meters. On the ground floor, the living-dining room has an area of $56 \mathrm{~m}^{2}$ and features four windows of $1.20 \times 1.20$ meters, a balcony door of $1.20 \times 2.10$ meters, and an access door of $1.20 \times 2.10$ meters. On the upper floor, a $12.50 \mathrm{~m} 2$ bedroom was chosen, having a $1.20 \times 1.20$ meter window and a $0.82 \times 2.10$ meter access door. In these habitable places, the measurement team took readings on eight days from April to June 2018. Four samples were without ventilation and another four after natural ventilation. The interval established for the measurements was 180 minutes ( 3 hours), because measurements with an interval of less than 60 minutes presented a high \% error. Therefore, a total of 32 measurements without ventilation plus 32 with ventilation were gathered over the eight days. Data on external meteorological conditions (temperature, atmospheric pressure, relative humidity and rainfall) were also recorded.

Figure 5. Location of the measuring device in the basement, ground floor and upper floor
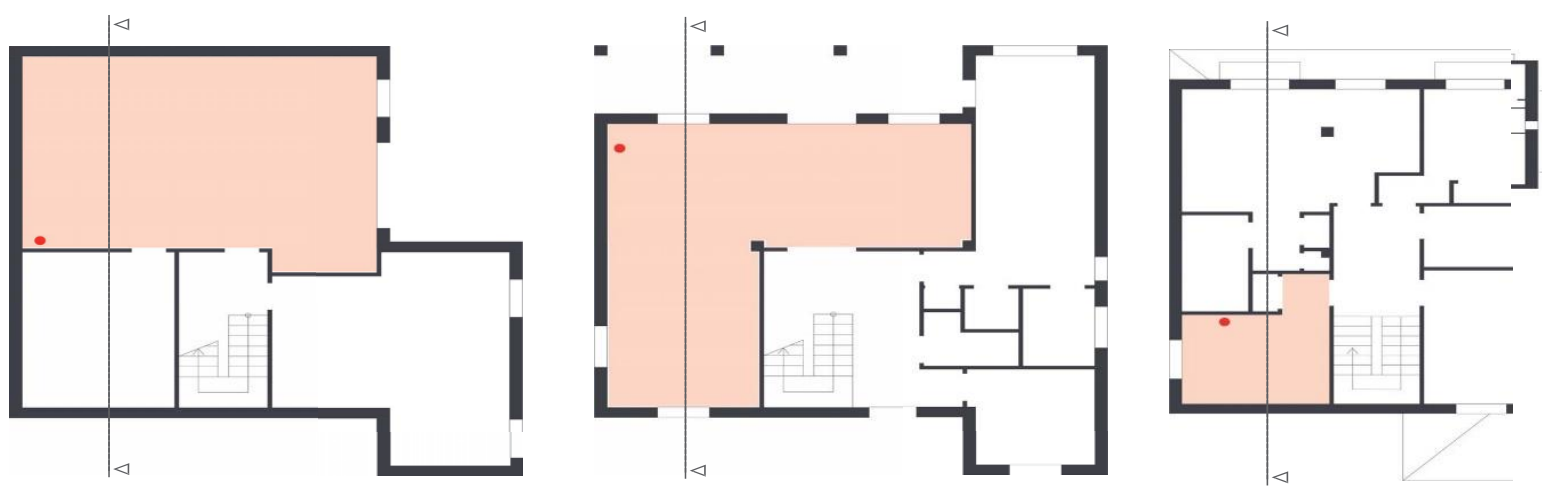

The main weather conditions obtained during the Radon measurement period (4 days per room) are reflected in Table 1. They are within the average values established for the town of Dúdar by the State Meteorological Agency (AEMET) for the measurement dates, hence considered stable.

Table 1. Climatological characteristics during sampling period. Source: the authors.

\begin{tabular}{|c|c|c|c|c|c|c|c|}
\hline Floor & Room & Start & End & $\begin{array}{l}\text { Outside } \\
\text { temp. }\end{array}$ & $\mathrm{RH}(\%)$ & $\begin{array}{l}\text { Precipitation } \\
(\mathrm{mm})\end{array}$ & $\begin{array}{l}\text { Pressure } \\
\quad(\mathrm{Pa})\end{array}$ \\
\hline \multirow{2}{*}{$\begin{array}{l}\text { Base- } \\
\text { ment }\end{array}$} & Unventilated garage & $15 / 05 / 18$ & $18 / 05 / 18$ & 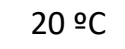 & 60 & 10 & 101600 \\
\hline & Ventilated garage & $24 / 04 / 18$ & $01 / 05 / 18$ & $17 \stackrel{\circ}{C}$ & 50 & 12 & 101400 \\
\hline \multirow[t]{2}{*}{ Ground } & $\begin{array}{l}\text { Living room without } \\
\text { ventilation }\end{array}$ & $19 / 05 / 18$ & $27 / 05 / 18$ & 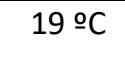 & 60 & 4 & 98000 \\
\hline & $\begin{array}{l}\text { Living room with } \\
\text { ventilation }\end{array}$ & $28 / 05 / 18$ & $31 / 05 / 18$ & 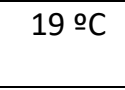 & 63 & 8 & 93000 \\
\hline \multirow[t]{2}{*}{ Upper } & Unventilated bedroom & $13 / 06 / 18$ & $16 / 06 / 18$ & $20.5 \stackrel{\circ}{ } \mathrm{C}$ & 60 & 4 & 93000 \\
\hline & Ventilated bedroom & $19 / 06 / 18$ & $22 / 06 / 18$ & $22 \stackrel{\circ}{ } \mathrm{C}$ & 58 & 3 & 91000 \\
\hline
\end{tabular}

After collecting the above data, the team proceeded to download and analyze the results.

In the basement, and during the interval under study without ventilation, a mean Radon gas concentration of 278.86 $\mathrm{Bq} / \mathrm{m}^{3}$ was obtained, whereas the total exposure during the measurement interval was $26733.45 \mathrm{Bqh} / \mathrm{m}^{3}$. The $\mathrm{standard}$ deviation of the data obtained was $56.32 \mathrm{~Bq} / \mathrm{m}^{3}$ and the coefficient of variation was $0.21 \mathrm{~Bq} / \mathrm{m}^{3}$. 


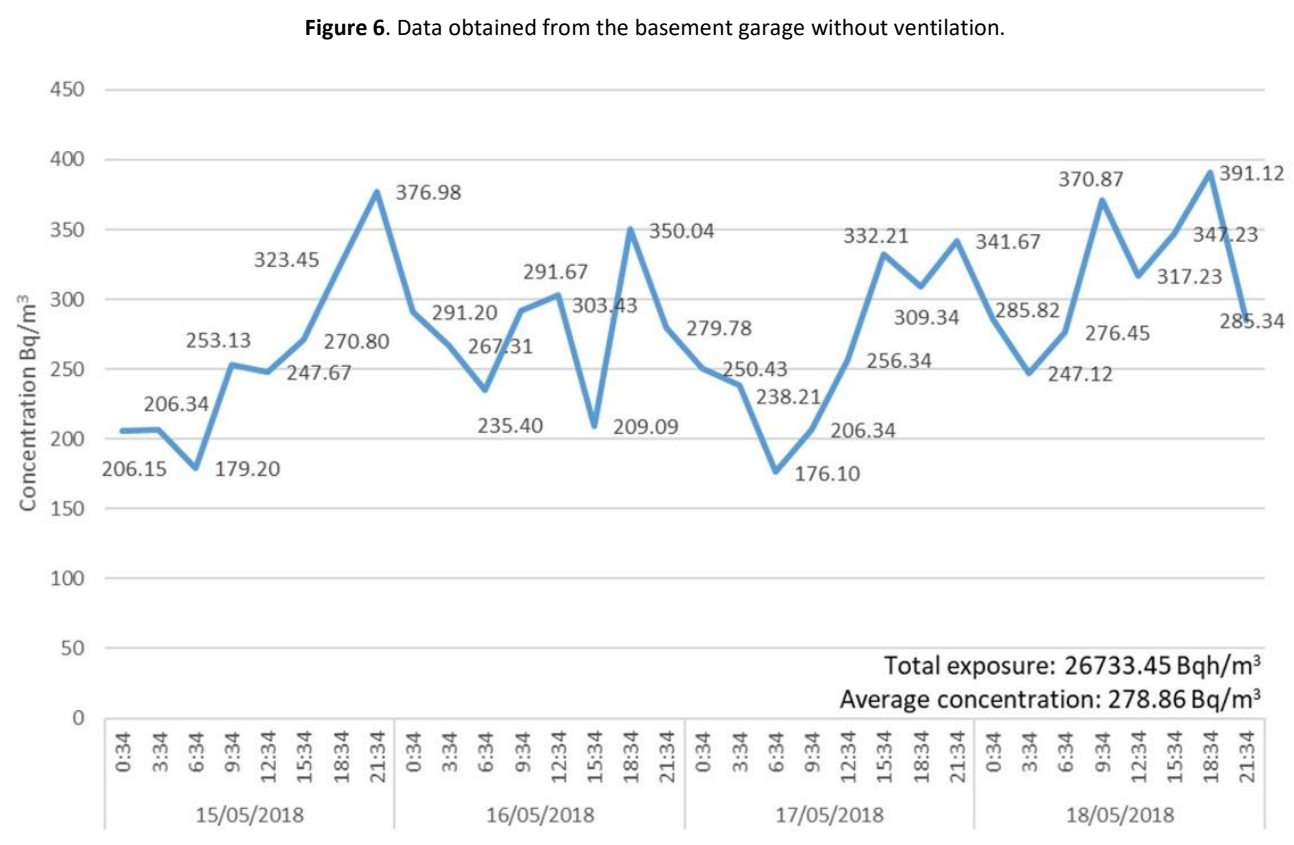

The highest concentration registered in the measurement interval was $391.12 \mathrm{~Bq} / \mathrm{m}^{3}$, obtained on May 18 at 1834 hours (see fig. 6). The lowest concentration value was $176.10 \mathrm{~Bq} / \mathrm{m}^{3}$, obtained on May 17 at 0634 hours. The indoor temperature values presented differences between maximum and minimum of $\pm 2{ }^{\circ} \mathrm{C}$; those of relative humidity, differences of $\pm 2 \%$, and atmospheric pressure variations of $\pm 300 \mathrm{~Pa}$.

During the intervals with ventilation, the mean Radon gas concentration was of $13.08 \mathrm{~Bq} / \mathrm{m}^{3}$, and the total exposure during the measurement interval was $1208.34 \mathrm{Bqh} / \mathrm{m}^{3}$. The standard deviation of the data obtained was $6.35 \mathrm{~Bq} / \mathrm{m}^{3}$ and the coefficient of variation was $0.29 \mathrm{~Bq} / \mathrm{m}^{3}$. The highest concentration in the measurement interval was 29.98 $\mathrm{Bq} / \mathrm{m}^{3}$, obtained on April 26 at 1846 hours. The lowest concentration value was $0 \mathrm{~Bq} / \mathrm{m}^{3}$, obtained on April 29 at 0646 and 0946 hours (see fig. 7). With respect to the indoor temperature values, they showed differences between maximum and minimum of $\pm 4{ }^{\circ} \mathrm{C}$; those of relative humidity, differences of $\pm 16 \%$ and atmospheric pressure variations of \pm 700 $\mathrm{Pa}$.

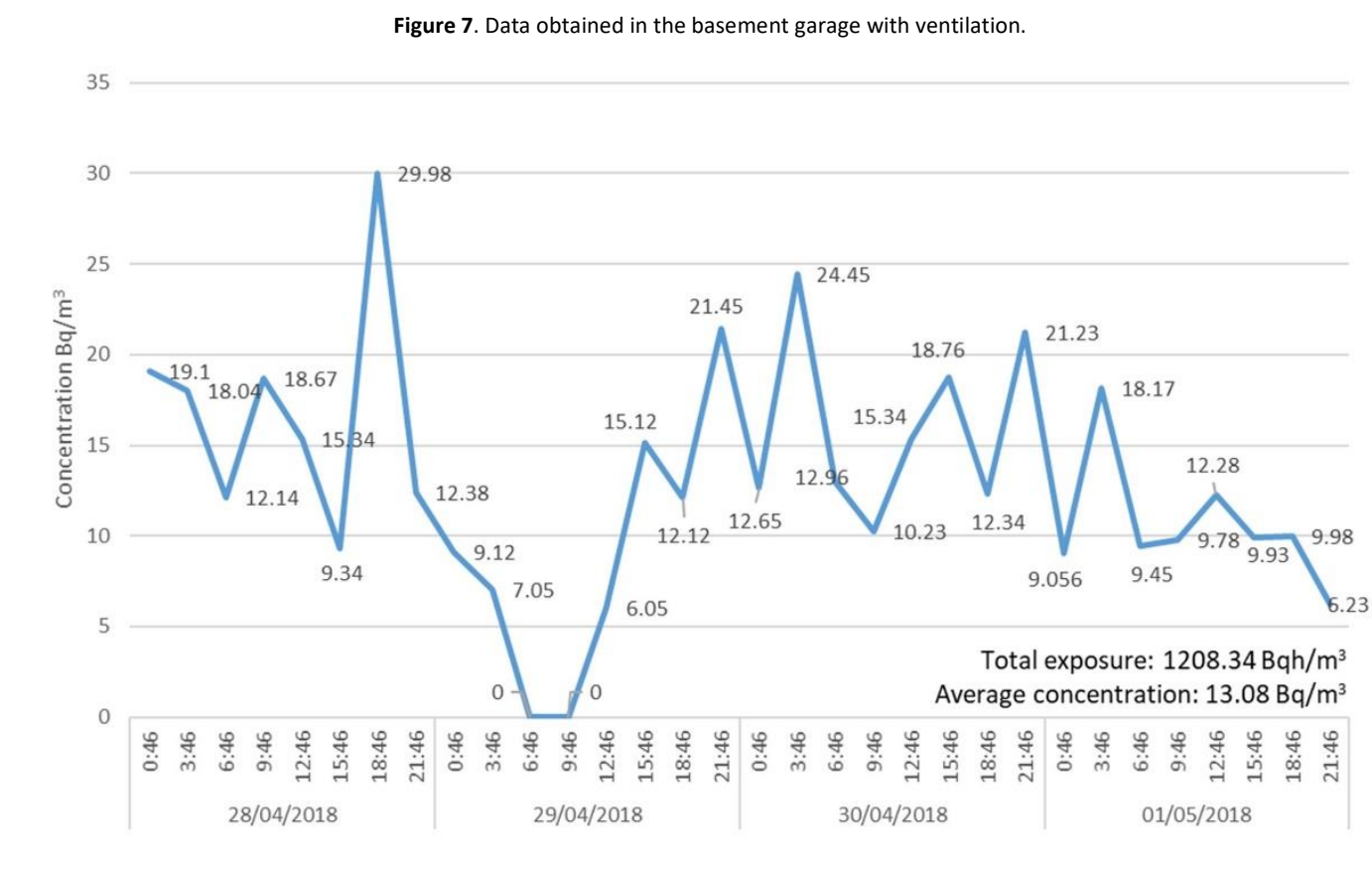


On the ground floor, and during the interval under study without ventilation, a mean Radon gas concentration of 69.95 $\mathrm{Bq} / \mathrm{m}^{3}$ was obtained and the exposure during the measurement interval was $6391.40 \mathrm{Bqh} / \mathrm{m}^{3}$. The standard deviation of the data obtained was $19.59 \mathrm{~Bq} / \mathrm{m}^{3}$ and the coefficient of variation was $0.50 \mathrm{~Bq} / \mathrm{m}^{3}$. The highest concentration value in the measurement interval was $103.26 \mathrm{~Bq} / \mathrm{m}^{3}$, obtained on May 22 at 0454 hours (see fig. 8). The lowest concentration value was $26.92 \mathrm{~Bq} / \mathrm{m}^{3}$ obtained on May 22 at 2254 hours. The indoor temperatures showed differences between maximum and minimum of $\pm 1.4^{\circ} \mathrm{C}$; those of relative humidity, differences of $\pm 6 \%$, and atmospheric pressure variations of $\pm 600 \mathrm{~Pa}$.

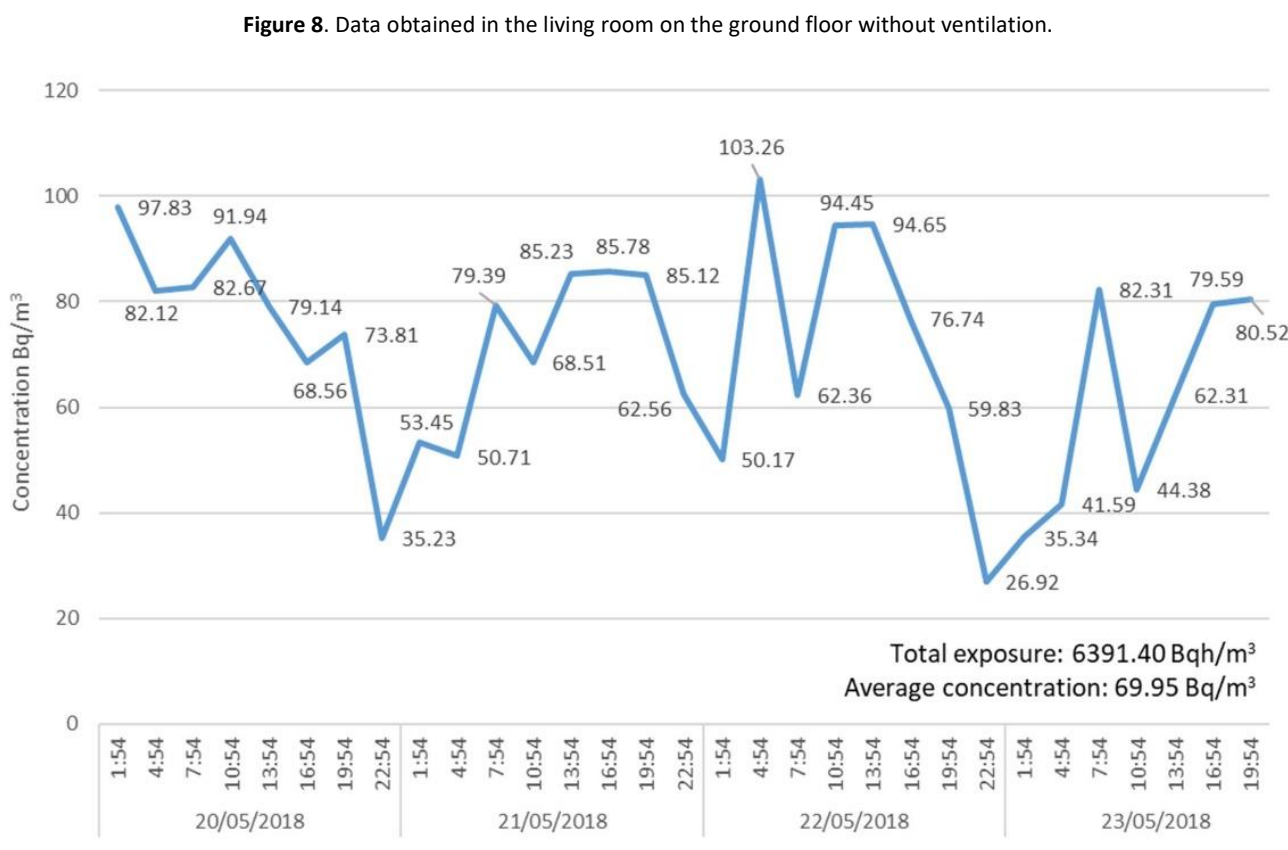

During the interval under study with ventilation, a mean Radon gas concentration of $27.81 \mathrm{~Bq} / \mathrm{m}^{3}$ was obtained, the total exposure amounting to $2625.67 \mathrm{Bqh} / \mathrm{m}^{3}$. The standard deviation of the data obtained was $8.62 \mathrm{~Bq} / \mathrm{m}^{3}$ and the coefficient of variation was $0.49 \mathrm{~Bq} / \mathrm{m}^{3}$. The highest concentration in the measurement interval was $47.82 \mathrm{~Bq} / \mathrm{m}^{3}$, obtained on May 31 at 1531 hours. The lowest value, $12.62 \mathrm{~Bq} / \mathrm{m}^{3}$, was registered on May 30 at 2131 hours (see fig. 9). The indoor temperature values varied $\pm 2{ }^{\circ} \mathrm{C}$; those of relative humidity, $\pm 8 \%$, and atmospheric pressure varied \pm 800 Pa.

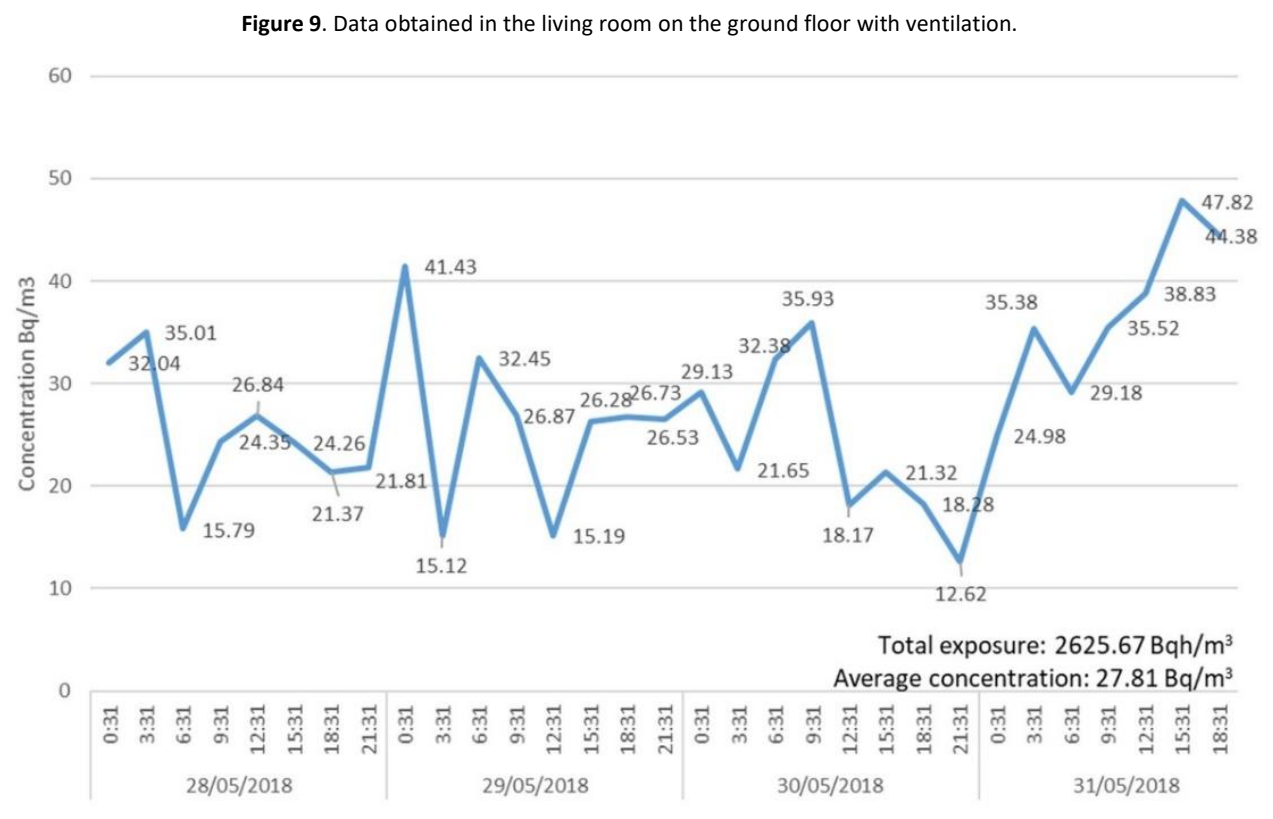


On the upper floor, and during the interval under study without ventilation, a mean Radon gas concentration of 41.28 $\mathrm{Bq} / \mathrm{m}^{3}$ was obtained and the total exposure was $3761.83 \mathrm{Bqh} / \mathrm{m}^{3}$.

Figure 10. Data obtained in the bedroom on the upper floor without ventilation.

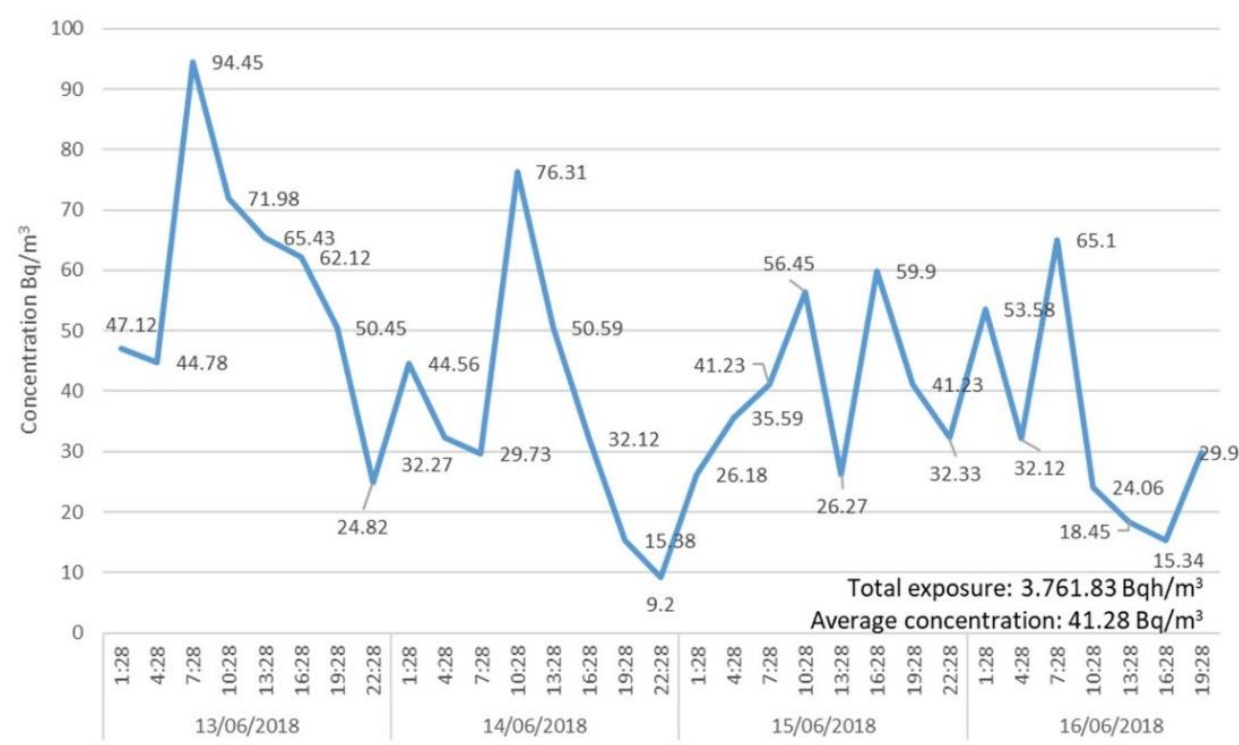

The standard deviation of the data obtained was $20.09 \mathrm{~Bq} / \mathrm{m}^{3}$ and the coefficient of variation was $0.31 \mathrm{~Bq} / \mathrm{m}^{3}$. The highest concentration was $94.45 \mathrm{~Bq} / \mathrm{m}^{3}$, recorded on June 13 at 0728 hours. The lowest value, $9.20 \mathrm{~Bq} / \mathrm{m}^{3}$, was obtained on June 14 at 2228 hours (see fig. 10). Indoor temperatures showed differences between maximum and minimum of \pm $1.4{ }^{\circ} \mathrm{C}$; those of relative humidity, differences of $\pm 7 \%$; and atmospheric pressure, variations of $\pm 800 \mathrm{~Pa}$.

During the interval under study with ventilation, a mean Radon gas concentration of $29.23 \mathrm{~Bq} / \mathrm{m}^{3}$ was obtained, total exposure amounting to $933.18 \mathrm{Bqh} / \mathrm{m}^{3}$. The standard deviation of the data obtained was $13.13 \mathrm{~Bq} / \mathrm{m}^{3}$ and the coefficient of variation was $0.46 \mathrm{~Bq} / \mathrm{m}^{3}$. The highest concentration was $71.56 \mathrm{~Bq} / \mathrm{m}^{3}$, on June 19 at 0717 hours. The lowest concentration value was $12.50 \mathrm{~Bq} / \mathrm{m}^{3}$, on June 22 at 1320 hours (see fig. 11). The indoor temperatures presented differences between maximum and minimum of $\pm 2^{\circ} \mathrm{C}$, those of relative humidity, differences of $\pm 10 \%$, and atmospheric pressure varied $\pm 400 \mathrm{~Pa}$. It should be noted that in this unit it was not possible to ventilate naturally during the complete interval of data collection - being a bedroom, and inhabited, the window had to be closed at night (2300 to 0700 hours) in order to achieve optimal habitability conditions. This circumstance is clearly reflected in figure 11: during the daytime, the Radon concentration decreases, whereas it increases at night.

Figure 11. Data obtained in the bedroom on the upper floor with ventilation.

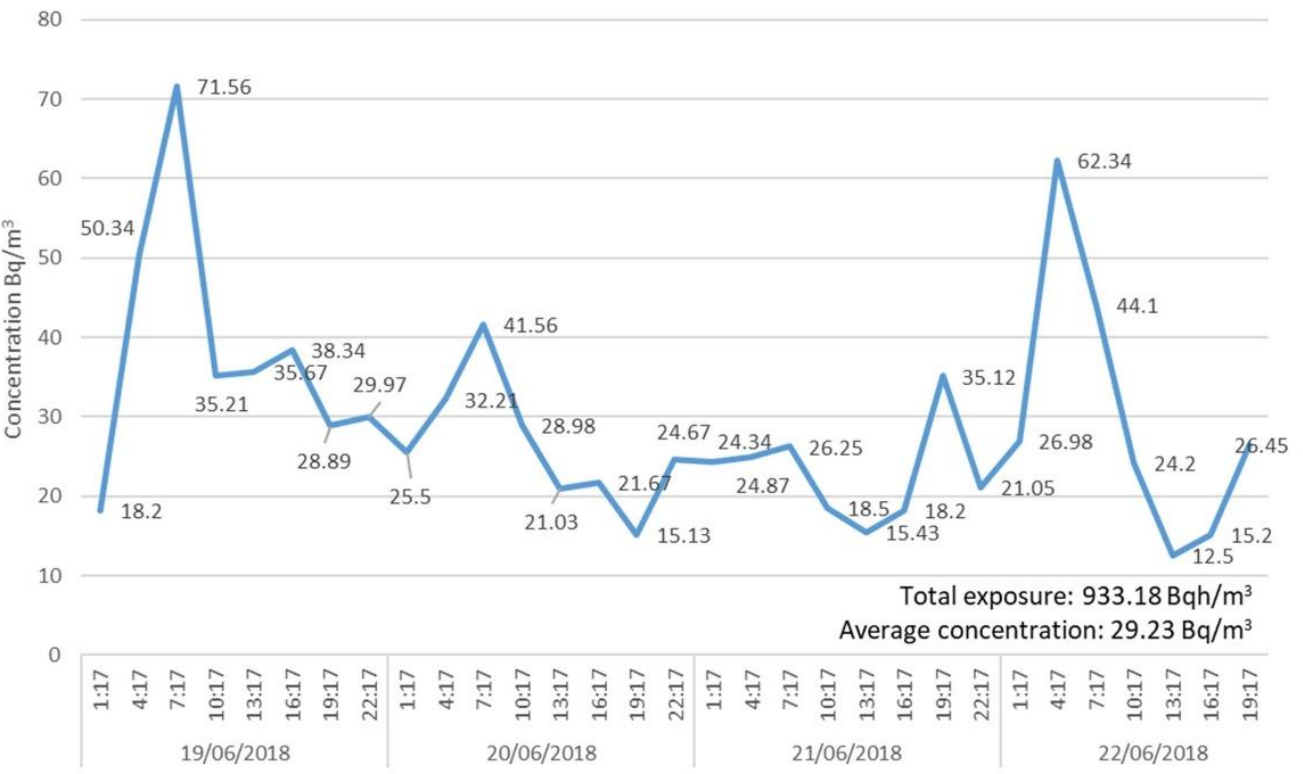


Figure 12 shows the statistics obtained in the different units for measurements without ventilation and with ventilation. It is seen that for the measurements carried out with ventilation, the mean values are above the median.

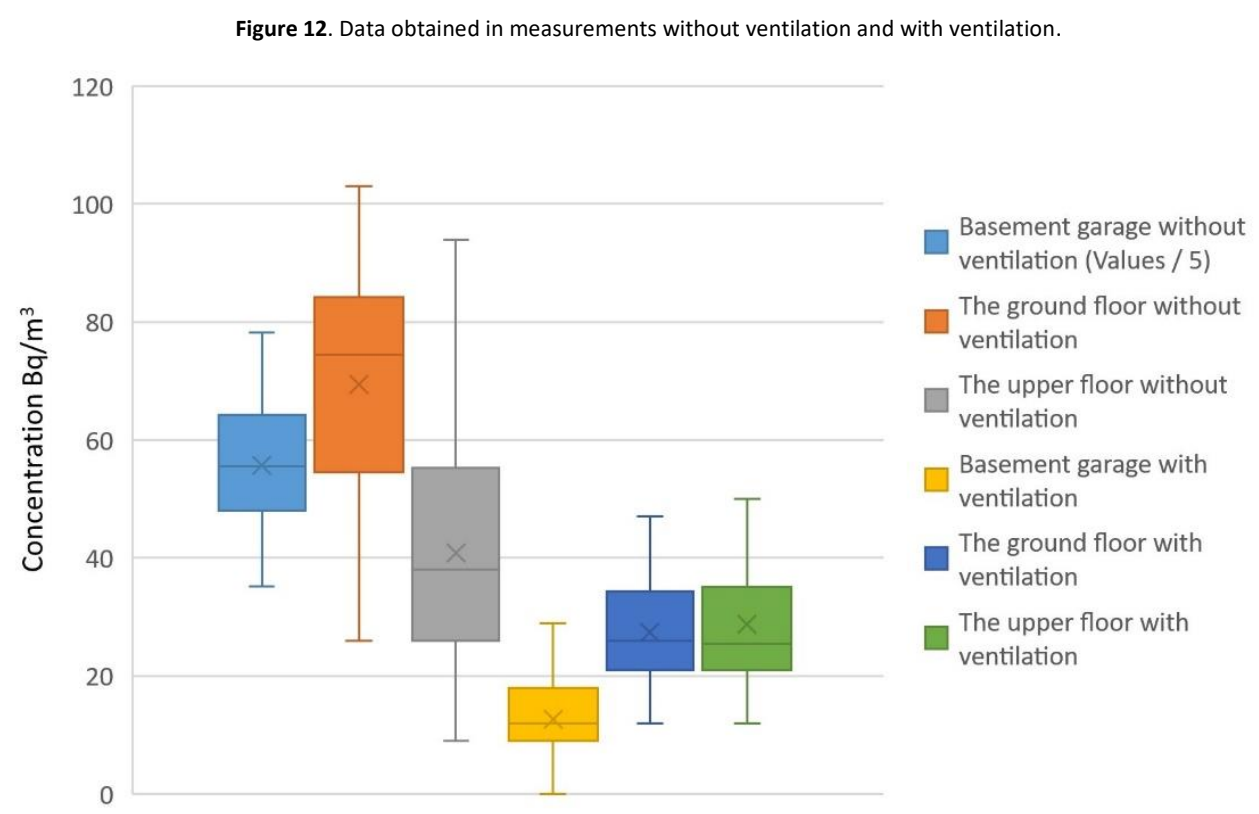

Tables 2 and 3 summarize the data on mean concentration, median, maximum and minimum values detected in the rooms of each floor when not ventilated versus yes ventilated.

Table 2. Average, median, maximum and minimum Radon concentrations without ventilation.

\begin{tabular}{|l|l|c|c|c|c|c|c|}
\hline \multicolumn{1}{|c|}{ Floor } & \multicolumn{1}{|c|}{ Room } & $\begin{array}{c}\text { Mean } \\
\text { Radon } \\
\left(\mathbf{B q} / \mathbf{m}^{3}\right)\end{array}$ & $\begin{array}{c}\text { Maximum } \\
\text { Radon } \\
\left(\mathbf{B q} / \mathbf{m}^{3}\right)\end{array}$ & $\begin{array}{c}\text { Minimum } \\
\text { Radon } \\
\left(\mathbf{B q} / \mathbf{m}^{3}\right)\end{array}$ & $\begin{array}{c}\text { Median } \\
\text { Radon } \\
\left(\mathbf{B q} / \mathbf{m}^{3}\right)\end{array}$ & $\begin{array}{c}\mathbf{9 5 \%} \\
\text { Confidence } \\
\text { Interval. } \\
\text { Higher }\end{array}$ & $\begin{array}{c}\mathbf{9 5 \%} \\
\text { Confidence } \\
\text { Interval. } \\
\text { Lower }\end{array}$ \\
\hline Basement & Garage & 278.86 & 391.12 & 176.40 & 278.11 & 298.27 & 258.67 \\
\hline Ground & $\begin{array}{l}\text { Living } \\
\text { room }\end{array}$ & 69.95 & 103.26 & 26.92 & 75.27 & 76.36 & 62.57 \\
\hline Upper & Bedroom & 41.28 & 94.45 & 9.20 & 38.41 & 47.93 & 33.82 \\
\hline
\end{tabular}

The average concentration ratio when ventilation is not carried out between the basement room and the ground floor room is 3.98, while the ratio between the ground floor and the upper floor room is 1.69 .

Table 3. Average, median, maximum and minimum concentrations of Radon with ventilation

\begin{tabular}{|l|l|c|c|c|c|c|c|}
\hline \multicolumn{1}{|c|}{ Floor } & Room & $\begin{array}{c}\text { Mean } \\
\text { Radon } \\
\left(\mathbf{B q} / \mathbf{m}^{3}\right)\end{array}$ & $\begin{array}{c}\text { Maximum } \\
\text { Radon } \\
\left.\mathbf{( B q} / \mathbf{m}^{3}\right)\end{array}$ & $\begin{array}{c}\text { Minimum } \\
\text { Radon } \\
\left(\mathbf{B q} / \mathbf{m}^{3}\right)\end{array}$ & $\begin{array}{c}\text { Median } \\
\text { Radon } \\
\left(\mathbf{B q} / \mathbf{m}^{3}\right)\end{array}$ & $\begin{array}{c}\mathbf{9 5 \%} \\
\text { Confidence } \\
\text { Interval. } \\
\text { Higher }\end{array}$ & $\begin{array}{c}\mathbf{9 5 \%} \\
\text { Confidence } \\
\text { Interval. } \\
\text { Lower }\end{array}$ \\
\hline Basement & Garage & 27.81 & 47.82 & 12.62 & 26.79 & 15.32 & 10.85 \\
\hline Ground & $\begin{array}{l}\text { Living } \\
\text { room }\end{array}$ & 41.28 & 94.45 & 9.20 & 38.41 & 30.84 & 24.77 \\
\hline Upper & Bedroom & 29.23 & 71.56 & 12.50 & 25.88 & 33.85 & 24.61 \\
\hline
\end{tabular}

The average concentration ratio when ventilation is carried out between the basement room and the ground floor room is 0.67 , while the relation between the ground floor room and the upper floor room is 1.41 . 
Given the reduction in the mean Radon concentration values when ventilation occurs and in view of the initial values without ventilation, these data give an efficiency value of $95.32 \%$ for the ventilation system used in the basement, $60.87 \%$ on the ground floor, and $29.27 \%$ on the upper floor.

Spain's Technical Building Code stipulates (in Basic Document HS-3), for indoor air quality, the calculation to be used when determining the flow of outdoor air needed to guarantee optimal environmental conditions within closed areas. It must be sufficient to eliminate $\mathrm{CO}^{2}$ as well as pollutants not related to human presence (MD, 2017). Table 4 indicates the minimum ventilation flows based on what is established in tables 2.1 and 2.2 of the TBC-DB-HS-3 for the different units of our sample home.

Tabla 4. Minimum ventilation flows for homes according to TBC-DB-HS-3.

\begin{tabular}{|c|c|c|c|}
\hline Floor & Room & Min. flow (I/s) & $\begin{array}{c}\text { Floor flow } \\
(\mathrm{I} / \mathrm{s})\end{array}$ \\
\hline \multirow[t]{2}{*}{ Basement } & Garage & 120 & \\
\hline & Supply room & $2 \times 10$ & $\begin{array}{c}\text { Not } \\
\text { habitable }\end{array}$ \\
\hline \multirow{4}{*}{ Ground } & Living room & 10 & \multirow[b]{4}{*}{36} \\
\hline & Dining room & 10 & \\
\hline & Kitchen & 8 & \\
\hline & Bathroom & 8 & \\
\hline \multirow[t]{2}{*}{ Upper } & Bedrooms & $8+4+4$ & \multirow[b]{2}{*}{32} \\
\hline & Bathrooms & $2 \times 8$ & \\
\hline \multicolumn{3}{|c|}{ TOTAL HOUSING FLOW (maximum) } & 36 \\
\hline
\end{tabular}

Taking into account that the constructed area of the house is $330 \mathrm{~m}^{2}$ and the volume to be ventilated is $924 \mathrm{~m}^{3}$, it is possible to calculate the rate of air renewal per hour necessary to comply with the provisions of the TBC-DB-HS-3, using the formula:

$$
Q_{\text {Ren }}=\frac{Q \times 3,6}{V}
$$

where, $\mathrm{Q}=$ Total air flow in home $(\mathrm{l} / \mathrm{s}), \mathrm{V}=$ House volume $\left(\mathrm{m}^{3}\right)$ and $\mathrm{Q}_{\text {renv }}=$ Total flow (renewals/hour).

This house is found to require 0.14 air changes per hour to maintain optimal conditions inside the premises.

Discussion

Through this investigation, the concentration of Radon in the interior spaces of a single-family residence was analyzed in order to assess any possible health hazard, and evaluate the efficiency of ventilation in keeping air quality parameters within the ranges set by legislation and explored by other research efforts. The mean concentrations for the units studied in the absence of ventilation were: basement, $278.86 \mathrm{~Bq} / \mathrm{m}^{3}$; ground floor, $69.95 \mathrm{~Bq} / \mathrm{m}^{3}$ and upper floor, 41.28 $\mathrm{Bq} / \mathrm{m}^{3}$. The standard deviation of the data obtained were: basement, $56.32 \mathrm{~Bq} / \mathrm{m}^{3}$; ground floor, $12.31 \mathrm{~Bq} / \mathrm{m}^{3}$ and upper floor, $19.59 \mathrm{~Bq} / \mathrm{m}^{3}$. These values lie within the ranges obtained by other authors (Frutos et al., 2018; Frutos et al., 2011; Martín et al., 2012; Piedecausa \& Frutos, 2018; Piedecausa, 2013; Quindós et al.,1995; Ruano et al., 2018) in studies of buildings having similar characteristics and age, supporting the measurements we report. The median values were: basement, $278.11 \mathrm{~Bq} / \mathrm{m}^{3}$, ground floor, $75.27 \mathrm{~Bq} / \mathrm{m}^{3}$ and upper floor, $38.41 \mathrm{~Bq} / \mathrm{m}^{3}$. The maximum concentrations registered in the units were: basement, $391.12 \mathrm{~Bq} / \mathrm{m}^{3}$; ground floor, $103.26 \mathrm{~Bq} / \mathrm{m}^{3}$; upper floor, $94.45 \mathrm{~Bq} / \mathrm{m}^{3}$.

When the basement of the house was not ventilated, the average concentration recorded did not surpass the value of $300 \mathrm{~Bq} / \mathrm{m}^{3}$ established in Directive 2013/59 EURATOM and Instruction I-33, which calls for the adoption of corrective measures in workplaces or public rooms containing such concentrations of Radon; yet $37.5 \%$ of our individual basement measurements without ventilation were over this limit. The basement exceeds the maximum value of $100 \mathrm{~Bq} / \mathrm{m}^{3} \mathrm{set}$ by the WHO throughout the period of study. Yet in general, the average values obtained on the ground floor and the upper floor are below this limit, and also within range of values obtained in similar investigations (Frutos et al., 2018; Frutos et al., 2011; Martín et al., 2012; Piedecausa \& Frutos, 2018; Piedecausa, 2013; Quindós et al.,1995; Ruano et al., 2018).

In contrast, the measurements made during periods when the dwelling units were ventilated do not exceed the maximum concentration value of $300 \mathrm{~Bq} / \mathrm{m}^{3}$ established in Directive 2013/59 EURATOM and Instruction I-33. The average values were: basement, $27.81 \mathrm{~Bq} / \mathrm{m}^{3}$; ground floor, $41.28 \mathrm{~Bq} / \mathrm{m}^{3}$; and upper floor, $29.23 \mathrm{~Bq} / \mathrm{m}^{3}$. They are consistently below the limit of $100 \mathrm{~Bq} / \mathrm{m}^{3}$ set by the WHO. The fact that these values are in line with those of similar 
investigations lends validity to our measurements (Frutos et al., 2018; Frutos et al., 2011; Piedecausa \& Frutos, 2018; Quindós et al.,1995; Ruano et al., 2018). The median values were: basement, $26.79 \mathrm{~Bq} / \mathrm{m}^{3}$, ground floor, $38.41 \mathrm{~Bq} / \mathrm{m}^{3}$ and upper floor, $25.88 \mathrm{~Bq} / \mathrm{m}^{3}$. The maximum concentrations registered in the units were: basement, $47.82 \mathrm{~Bq} / \mathrm{m}^{3}$; ground floor, $94.45 \mathrm{~Bq} / \mathrm{m}^{3}$; upper floor, $71.56 \mathrm{~Bq} / \mathrm{m}^{3}$.

Among the premises established by the authors consulted (Barros et al., 2007; Font \& Baixeiras, 2003; Frutos et al., 2011; Narocki et al., 2018) that might modify gas concentrations inside buildings, the following stand out: type of soil, climatic conditions, age, materials, construction systems and ventilation installations. As our measurements were taken at the same house, only weather and ventilation conditions would affect variances in the Radon concentrations inside the building. The climatic conditions -interior temperature, relative humidity, rainfall and atmospheric pressureduring the data collection period (see table 1) presented minor variations. Authors Frutos et al. (2011) and the Nuclear Safety Council (2010) conclude from their research that the two main atmospheric parameters affecting Radon concentrations are rainfall and atmospheric pressure variations over 3,000 Pa. In our study, both of these factors remained constant throughout the measurements, and the pressure difference detected did not exceed the value indicated by the above reports. Therefore, in line with these and similar studies (Barros et al., 2007; Muñoz et al., 2017; Narocki et al., 2018; Piedecausa, 2013), it can be said that our research scenario was not affected by unstable outside atmospheric conditions.

According to the results of this research, and taking into account the average reduction in Radon concentration when natural basement ventilation is performed compared to measurements without ventilation, the efficiency is $95.32 \%$, that of the ground floor, $60.87 \%$, and that of the upper floor, $29.26 \%$. Looking at ventilation efficiency over the maximum Radon value, the data obtained are the following: $92.58 \%$ for the basement, $54.36 \%$ for the ground floor, and $24.46 \%$ for the upper floor. These data regarding the efficacy of natural ventilation are seen to be very similar for the Radon in mean and maximum concentrations, and lie in the range of values described elsewhere (Frutos et al., 2018; Frutos et al., 2011; Otero et al. al., 2017) - a noteworthy exception being the very low value obtained for the upper floor. The reason for this is that ventilation was unfeasible during the entire interval of data collection, because the bedroom window was closed at night (2300 to 0700 hours). Taking into account that the ventilation process covered two-thirds of the data collection schedule, the efficiency obtained if this bedroom window had not been closed would have been similar to that obtained on the ground floor, approximately $50 \%$ efficiency.

The contributions of this article should be analyzed in light of a limitation that justifies the development of future research: as other authors have appealed, (Otero et al., 2017; Piedecausa, 2013), taking measurements of longer duration (between 9 and 12 months) is a priority in order to fine-tune maximum and annual mean values, as well as possible fluctuations in concentration in the different seasons of the year. More precise results in this sense could help improve the implementation of measures intended to reduce the concentration of gas in buildings.

Conclusions

In recent decades, the study of Radon gas concentrations in building interiors has grown in importance, motivated by scientific and technological advances that continually shed light on the harmful effects of this gas and others on human health, and the need for more precise means of measurement.

In the context of our research, it can be concluded that the mean Radon concentration values in the dwellings studied are below the limit of $300 \mathrm{~Bq} / \mathrm{m}^{3}$ established by the 2013/59 EURATOM standard and the TBC. However, $37.5 \%$ of the concentration values obtained in the basement unit far exceeded the limit of $300 \mathrm{~Bq} / \mathrm{m}^{3}$ - and as they triple the maximum concentration recommended by the $\mathrm{WHO}$, they should be considered detrimental to the health of the people living in the house studied here.

The Radon concentration values were found to be higher in the basement unit, which lies in contact with the soil, than in the upper floors. The basement can be considered a main entryway for gas into the building, even in this case, involving a home located in an area whose soil type is categorized as having low potential exposure to Radon. The risk might therefore be greater in soil categories with high exposures.

The efficacy values of the natural ventilation system used to decrease concentrations were: $95.32 \%$ in the basement, $60.87 \%$ on the ground floor, and $29.26 \%$ on the upper floor. This gives an average ventilation efficiency of $62 \%$. Altogether, it is verified that the natural ventilation system in the home constitutes an effective technique for the control of Radon concentrations, although it does not eliminate the gas completely. 
In the field of practice, this research makes a significant contribution to the study of environmental concentrations of Radon in closed places. Although the data obtained underline the efficiency of natural ventilation systems, ventilation does not suffice to completely eliminate the pollutant from closed environments. Organizations, architects, builders and managers assigned to the building sector must take this fact into account, adopting appropriate measures to minimize the concentration of this Radon in buildings, and particularly in residential buildings. The values reported here for the ground floor and upper floor do not exceed the regulatory guideline values established, but the risk of developing cancerous diseases calls for a reduction of the maximum annual values and average concentrations. The implementation of control plans, the installation of detectors, and the practice of periodic measurements in closed areas are recommended, in line with the provisions of Technical Building Code DB-HS-6.

\section{Acknowledgment}

This work was carried out thanks to support by the University of Granada and its Department of Radiology and Physical Medicine. Without their selfless collaboration, this study would not have been possible.

References

AENOR-ISO (2016). UNE-ISO 11665-1. Origins of Radon and its short-lived decay products and associated measurement methods. Spanish Association for Standardization (SAS).

Axelson, O., Edling, C. \& Kling, H. (1979). Lung cancer and residency--a case-referent study on the possible impact of of exposure to Radon and its daughters in dwellings. Scandinavian Journal of Work, Environment \& Health, 5(1),10-15.

Barros, J. M., Ruano, A., Gastelu, J. \& Figueiras, A. (2007). Factors underlying residential Radon concentration: Results from Galicia, Spain. Environmental Research, 103, 185-190. https://doi.org/10.1016/j.envres.2006.04.008

Barros, J.M., Barreiro, M.A., Ruano, A. \& Figueiras, A. (2002). Exposure to residential Radon and lung cancer in Spain: A population-based: Case-control study. American Journal of Epidemiology, 156(6),548-555.

Catelinois, O., Rogel, A., Laurier, D., Billon, S., Hemon, D, \& Verger, P. (2006). Lung cancer attributable to indoor Radon exposure in France: impact of the risk models and uncertainty analysis. Environmental Health Perspectives, 114(9),1361-1366.

CEU (Council of the European Union). (2014). Council Directive 2013/59 / EURATOM of December 5, 2013, which establishes basic safety standards for protection against the dangers arising from exposure to ionizing radiation. Official Journal of the European Union, n.13, pp. 1-73.

Dueñas, C., Fernández, M.C., Cañete, S., Pérez, M. \& Gordo, E. (2011). Seasonal variations of Radon and the radiation exposure levels in Nerja cave, Spain. Radiation Measurements, 46, 1181-1186. https://doi.org/10.1016/j.radmeas.2011.06.039

Font, LI. \& Baixeiras, C. (2003). The RAGENA dynamic model of Radon generation, entry and accumulation indoors. The Science of the Total Environment, 307, 55-69. DOI: 10.1016/S0048-9697(02)00462-X

Frutos, B., Muñoz, E., Olaya, Alonso, C. \& Martín, D., (2018). Singularities in the design of protection solutions against Radon gas. Anales de Edificación, 4(2), 32-39. DOI: 10.20868/ade.2018.3776.

Frutos, B., Olaya, M., Martín, F., \& Alonso, C., (2014). Study of the energy cost associated with the loss of thermal comfort due to the application of a ventilation technique implemented in a home in order to reduce Radon concentration. In M. Neznal. 12th International Workshop on the Geological Aspects of Radon Risk Mapping, Czech Republic.

Frutos, B., Olaya, M. \& Esteban, J.L. (2011). Extraction system as a construction technique to prevent the entry of Radon gas into the home. Informes de la Construcción, 63 (521), 23-36. Doi: 10.3989/ic.09.056

García, M., López, F.J., Sanz, M.T., Ramos, L. \& Sánchez, M.F., (2017). Towards a Nuclear Plan against Radon in Spain. Revista Alfa, 34,2 -3.

IGME (Geological and Mining Institute of Spain). (2019). Type of soils in Spain. Recovered from: http://mapas.igme.es/Servicios/default.aspx?lang=spa [Access Date: October 21, 2020].

IARC (Monographs on the evaluation of carcinogenic risks to humans). (1988). Man-made mineral fibers and Radon. World Health OrganizationInternational Agency for Research on Cancer.

IED. US EPA, OAR, Radon: Assessment of Risks from Radon in Homes. [Online]. Recuperado de: https://www.epa.gov/Radon/health-risk-Radon [Access Date: October 21, 2020].

Lamonaca, F., Nastro, V., Nastro, A. \& Grimaldi, G. (2014). Monitoring of indoor Radon pollution. Measurement, 47, $228-233$. https://doi.org/10.1016/j.measurement.2013.08.058

Lario, J., Sánchez, S., Cañaveras, J.C., Cueva, S. \& Soler, V. (2005). Radon continuous monitoring in Altamira Cave (northern Spain) to assess user's annual effective dose. Journal of Environmental Radioactivity, 80, 161-174. http://dx.doi.org/10.1016/j.jenvrad.2004.06.007

Liu, B., Peng, T., Sun, J. \& Yue, H. (2017). Release behavior of uranium in uranium mill tailings under environmental conditions. Journal Environmental Radioactivity, 171, 160-168, https://doi.org/10.1016/j.jenvrad.2017.02.016

Martín, A., De la Torre, J., Ruano, A.B. \& Naranjo, F.L. (2012). Radon in workplaces in Extremadura (Spain). Journal of Environmental Radioactivity, 107, 86-91. http://dx.doi.org/10.1016/j.jenvrad.2012.01.009 
Miles, J., Appleton, J.D., Rees, D.M., Green, B., Adlam, K. \& Myers, A. (2007). Indicative Atlas of Radon in England and Wales: HPA-RPD-033. Didcott, Oxfordshire, UK: Health Protection Agency.

MD (Ministry of Development). (2018). Draft Royal Decree by which Royal Decree 314/2006, of March 17, is modified, by which the TBC (Technical Building Code) is approved. Recovered from: https://www.boe.es/buscar/act.php?id=BOE-A-2006-5515 [Access Date: October 21, 2020]

MD (Ministry of development). (2017). Technical building Code. Basic Document HS-3: indoor air quality. Recovered from: https://www.codigotecnico.org/images/stories/pdf/salubridad/DBHS.pdf [Access Date: October 21, 2020].

MP (Ministry of the Presidency). (2001). Regulation on health protection against ionizing radiation. State official newsletter, $\mathrm{n} 0178, \mathrm{pp}$. $27284-27393$. Spain.

MP (Ministry of the Presidency). (2010). Royal Decree 1439/2010, of November 5, which modifies the Regulation on health protection against ionizing radiation, approved by Royal Decree 783/2001, of July 6. State official newsletter, no 279, pp. 96395 a 96398 . Spain.

Muñoz, E., Frutos, B., Olaya, M. \& Sánchez, J. (2017). A finite element model development for simulation of the impact of slab thickness, joint and membranes on indoor Radon concentration. Journal of Environmental Radioactivity, 177, 280-289. https://doi.org/10.1016/j.jenvrad.2017.07.006

NSCS (Nuclear Safety Council Spain). (2013). Map of risk levels in Spain. Recovered from: https://www.csn.es/mapa-del-potencial-de-Radon-enespana. [Access Date: October 21, 2020].

NSCS (Nuclear Safety Council Spain). (2011). Instruction IS-33, of December 21, 2011, of the Nuclear Safety Council, on radiological criteria for protection against exposure to natural radiation. State official newsletter, no 22, pp. 6833-6838.

NSCS (Nuclear Safety Council Spain). (2010a). Radiation dose. Technical Reports Collection, SDB-04.07, 13.

NSCS (Nuclear Safety Council Spain). (2010b). Protection against Radon gas immission in buildings. Technical Reports Collection, SDB-24.2010

Otero, A., Fernández, I., Piñón, A.J., Calvo, J.L. \& Giz, J. (2017). Study, measurement and mitigation of Radon concentration at the Higher Technical School of Technical Architecture of the Universidade da Coruña. Informes de la Construcción, 69 (547), 1-11. http://doi.org/10.3989/ic.16.101

Piedecausa, B. \& Frutos, B. (2018). Radon concentrations in cave houses of Crevillente. A study about typological factors and proposals for remedial actions based on ventilation techniques. Revista de la Construcción, 17 (1), 60-71. https://doi.org/10.7764/RDLC.17.1.60

Piedecausa, B. (2013). Radon measurement in underground workspace of the Campus of the University of Alicante. Informes de la Construcción, (65), 531, 301-310. https://doi.org/10.3989/ic.12.093

Pinza, C., Alcaide, J.M., Rodríguez, R. \& Hernández, J. (1999). Radon exposures in caves of Tenerife (Canary Islands). Radiation Protection Dosimetry, 82, 219-224. http://dx.doi.org/10.1093/oxfordjournals.rpd.a032628

Quindós, L., Fernández, P., Sainz, C., Gómez, J. \& Bordonoba, M. (2004). Radon exposure in uranium mining industry vs exposure in tourist caves. Radiation Protection Dosimetry, 111, 41-44. http://dx.doi.org/10.1093/rpd/nch357

Quindós, L. S., Fernández, P. L. \& Soto, J. (1995). Study of areas of Spain with high indoor Radon. Radiation Measurements, $24(2), 207-221$. http://dx.doi.org/10.1016/1350-4487(94)00108-D

Rees, D.M., Bradley, E.J. \& Green, B.M.R. (2010). Radon in Homes in England and Wales: 2010 Data Review. Didcot, Oxfordshire: Centre for Radiation, Chemical, and Environmental Health, Health Protection Agency.

Ruano, A., Narocki, C., López, M.J., García, A., Calle, M.C., Peón, J. \& Barros, J.M. (2018). Indoor Radon in Spanich workplace: A pilot study before the introduction of the European Directive 2013/59/EURATOM. Gaceta universitaria, 1622, 1-5. https://doi.org/10.1016/j.gaceta.2018.05.006

SAAC (Spanish Association Against Cancer). (n.d.) Recovered from: https://www.aecc.es/es/todo-sobre-cancer/tipos-cancer/cancer-pulmon [Access Date: October 6, 2020]

Sainz, C., Dinu, A., Tiberius, T., Szacsval, K., Cosma, C. \& Quindós, L. S. (2009). Comparative risk assessment of residential Radon exposures in two Radon-prone areas, Ştei (Romania) and Torrelodones (Spain). Science of the Total Environment, 407, 4452-4460. http://dx.doi.org/10.1016/j.scitotenv.2009.04.033

SARAD GmbH. (2009). Radon Scout Handbook EN 02-10-09. Recovered from: https://www.sarad.de/product-detail.php?p_ID=37\&cat_ID=2 [Access Date: October 21, 2020]

WHO (World Health Organization). (2015). Radon and health. [Online]. Available: http://www.who.int/mediacentre/factsheets/fs291/en/ [Access Date: October 21, 2020].

WHO (World Health Organization). (2014). Radon and its effects on health. № 291.

WHO (World Health Organization). (2009). World Health Organization handbook on indoor Radon: a public health perspective.

WHO (World Health Organization). (2000). Air Quality Guidelines for Europe. Copenhagen: Regional Publications, European Series, № 91. 